\title{
SSEASONAL ABUNDANCE AND HOST PLANT PREFERENCE OF CERTAIN APHIDS SPECIES INFESTING SOME CITRUS TREES ORCHARDS \\ El-Gindy, M. $A^{1}$ and Ola E. Hegab ${ }^{2}$ \\ ${ }_{1}$ Plant Protection Research Institute ,ARC, Egypt. \\ ${ }^{2}$ Fac. Agric. , Zagazig Univ. Egypt
}

\begin{abstract}
These studies were carried out in El-Mansoura district, Dakahlia Governorate during the two seasons of 2004/2005 and 2005/2006 on different citrus trees (Navel orange, Mandalin and Valencia orange). The present study illustrated that Aphis gossypii Glover, Aphis citricola (V.D. Goot) had two peaks at April and August during the two seasons of investigation. While, Myzus persicae (Sulzer) and Aphis craccivora Koch had one peak occurred during March and April for the two seasons. Each aphid species showed different degrees of preference for the different tested citrus trees. A. gossypii exhibited higher population on Mandarin trees. While Navel orange receive the highest population of $A$. citricola and $M$. persicae. The weather factors play a great role on the population density and seasonal abundance of the tested aphid species.
\end{abstract}

\section{INTRODUCTION}

A. gossypii Glover, A. citricola (V.D. Goot), M. persicae (Sulzer) and A. craccivora Koch are among the main insect pests infesting citrus trees. These species are great economic importance as vectors of virus diseases to citrus trees (Bertolini et al. 2004).

The interaction of aphid species with these host plants is a complex problem suggesting many intriguing questions. The biology of the insects is strongly influenced by the host tissue content. The more favorable substrate had comparatively faster maturation, higher percentage of juvenile survivorship and greater reproduction rates (Abd El- Kareim, 1988). For the success of integrated pest management control program (IPM), it is essential top know in detail several information concerning the population dynamics of the pest. The influence of weather factors (i.e temperature and relative humidity are of great important especially on aphid populations.

Therefore the present investigation aimed to study the following pointes.

1. Seasonal abundance of the dominant aphid species by using different sampling methods.

2. Influence of host plant species on aphid population

3. Effect of temperature and relative humidity on the population density of the aphid species

\section{MATERIALS AND METHODS}

\section{Ecological studies on certain aphid species infesting some citrus orchards.}

The field experiments were carried out at El-Mansoura district, Dakahlia Governorate during 2004/2005 and 2005/2006, seasons. Study the seasonal abundance of the dominant aphid species Aphis gossypii Glover, Myzus 
persicae (Sulzer), Aphis craccivora Koch and Aphis citricola (V.D. Goot) on citrus trees, different sampling methods were carried out throughout the two seasons. Five trees were chosen randomly from each citrus species (Navel orange, Mandarin and Valencia orange).

The sampling methods were as follow:

\section{1- $\quad$ Plant samples}

Weekly samples of 20 leaves were picked up randomly from each trees (five trees). The leaves were placed in paper bag and transported to the laboratory in the same day for inspection by the Stereomicroscope. The actual number of aphid on both leaf surfaces were counted and recorded.

2- Yellow sticky board trap.

Double yellow paper card $24.5 \times 12 \mathrm{~cm}$ were coated with a sticky material and hung on a branch of each citrus tree. The cards were changed weekly by new ones; the captured insects were identified according to Habib and El-Kady (1961) and counted to determine their population density.

\section{3- Yellow pan trap}

Yellow plastic pan of $30 \mathrm{~cm}$ diameter and $10 \mathrm{~cm}$ deep filled with water were used for estimating aphid population. These traps were hangs on wooden rods among the tested trees. The water in each trap was changed weekly by new one. The captured insects were counted and recorded. Ten traps from each of Yellow sticky board and yellow pan traps were used in this investigation. Daily records of both maximum and minimum temperature along with relative humidity were obtained from the Agrometrological station at El-Mansoura region to represent the climatic condition effects during 2004 / 2005 and 2005 / 2006 seasons. The relationship between the weekly number of insects and the corresponding weekly means of maximum, minimum temperature and relative humidity were estimated.

Partial regression was applied to show the effect of each factor on the population density of each insects species.

Data were subjected to the analysis according to Svab (1973).

\section{RESULTS AND DISCUSSION}

\section{The potential of sampling methods}

The total number of each aphid species collected by using the different sample methods was illustrated in table (1). Data presented in table (1) reveled that the plant sample proved to be the more efficient methods for estimating aphid population. However the total number of each aphid species (A. gossypii Glover, A. citricola (V.D. Goot), M. persicae (Sulzer) and A. craccivora Koch) was considerably higher than those collected by yellow sticky board or yellow pan traps. For plant samples it is worth to mention that A. gossypii was the most abundance aphid species followed by $A$. citricola, $M$. persicae and $A$. craccivora, respectively during the two seasons. These results are in agreement with the finding of Attia (1983) Attia and El-Kady (1986), Chen and Wong (1998) and Amer (2002). 
Table (1): Total number of aphid species infesting citrus trees at Dakahlia Governorate Egypt collected by using different sampling methods (plant samples, Yellow sticky board trap and yellow pan traps) during 2004/2005 and 2005/2006, seasons.

\begin{tabular}{|c|c|c|c|c|c|c|c|}
\hline \multirow{2}{*}{ Aphid species } & \multirow{2}{*}{ Host plant } & \multicolumn{5}{|c|}{ Total number of aphids/sample } \\
\cline { 3 - 8 } & & Plant s. & $\begin{array}{c}\text { Y. S. B. } \\
\text { T. }\end{array}$ & Y. P. T. & Plant s. & $\begin{array}{c}\text { Y. S. B. } \\
\text { T. }\end{array}$ & Y. P. T. \\
\cline { 2 - 8 } & Navel orange & 3939 & 273 & 86 & 3274 & 214 & 73 \\
\hline \multirow{3}{*}{$\begin{array}{c}\text { Aphis gossypii } \\
\text { Glover }\end{array}$} & Mandarin & 5543 & 310 & 113 & 4621 & 223 & 91 \\
\cline { 2 - 8 } & $\begin{array}{c}\text { Valencia } \\
\text { orange }\end{array}$ & 3515 & 198 & 74 & 2925 & 132 & 62 \\
\hline \multirow{2}{*}{$\begin{array}{c}\text { Aphis citricola } \\
\text { (V.D. Goot) }\end{array}$} & Navel orange & 2762 & 156 & 69 & 2239 & 120 & 48 \\
\cline { 2 - 8 } & Mandarin & 1548 & 117 & 54 & 1415 & 53 & 19 \\
\cline { 2 - 8 } & $\begin{array}{c}\text { Valencia } \\
\text { orange }\end{array}$ & 2359 & 134 & 70 & 2151 & 89 & 35 \\
\hline \multirow{3}{*}{$\begin{array}{c}\text { Myzus persicae } \\
\text { (Sulzer) }\end{array}$} & Navel orange & 1427 & 93 & 46 & 1332 & 67 & 20 \\
\cline { 2 - 8 } & Mandarin & 725 & 43 & 27 & 667 & 39 & 14 \\
\cline { 2 - 8 } & $\begin{array}{c}\text { Valencia } \\
\text { orange }\end{array}$ & 1210 & 81 & 32 & 1136 & 53 & 22 \\
\hline \multirow{2}{*}{$\begin{array}{c}\text { Aphiscraccivora } \\
\text { Koch }\end{array}$} & Mavel orange & 1037 & 57 & 22 & 973 & 44 & 26 \\
\cline { 2 - 8 } & $\begin{array}{c}\text { Valencia } \\
\text { orange }\end{array}$ & 667 & 25 & 16 & 622 & 18 & 10 \\
\hline
\end{tabular}

Plant S. = plant samples, Y. S. P. T = Yellow sticky board trap and Y. P. T. = yellow pan trap.

\section{I- Effect of host plant on aphid population}

\section{1- A. gossypii population}

The total numbers of $A$. gossypii per a sample (100 leaves) collected from Navel orange trees during 2004/2005 and 2005/2006 are illustrated graphically in Figure (1).

During the investigation period $A$. gossypii population had two distinct peaks of seasonal abundance occurred on all tested citrus species.

As shown in figure (1) the first peak of $A$. gossypii population was recorded at mid April on Navel orange trees with total number of 1104 and 822 individuals/sample during the first and second seasons. The second peak was noticed at mid August with a total of 385 and 360 individuals/sample for the two seasons.

While on Mandarin trees the first peak occurred at the end of April with a total numbers of 1174 and 989 aphids/sample for the two seasons. The second one was recorded at the end of August with a total numbers of 412 and 381 individuals/sample for the two seasons.

While the first peak on Valencia orange trees was observed at mid April with total numbers of 710 and 583 aphids/sample for the two seasons. The second peak was recorded at mid August with total numbers of 410 and 386 aphids/ sample for the two seasons.

The obtained results indicated that $A$. gossypii exhibited higher population on Mandarin as compared to Navel orange or Valencia orange trees during the both years of study. 


\section{El-Gindy, M. A and Ola E. Hegab}

\section{2- Aphis citricola V.D. Goot}

The total number of $A$. citricola collected from each host plant during $2004 / 2005$ and $2005 / 2006$ are illustrated graphically in Figure (2). Two peaks for $A$. citricola population density were recorded on all tested citrus species. The first one was recorded at the mid April with a total number of 613 and 508 individuals/sample (on Navel orange) and 360\& 325 aphid/sample on Mandarin trees during the two seasons. The second one occurred at mid August with a total number of 311 and 293 Individuals /sample on navel orange and 118\& 109 insects/sample on Mandarin trees for the two seasons. While on Valencia orange the first peak was recorded at the end of March with a total numbers of 396 and 355 individuals/sample for both seasons. The second one was noticed at mid August with a total number of 292 and 286 aphids/sample for both seasons.

\section{3- Myzus persicae (Sulzer)}

The total numbers of $M$. persicae during two seasons of investigation are illustrated graphically in figure (3). As shown in figure (3) M. persicae population had one peak on all tested citrus species, occurred at mid April with the total number of 375 and 358 individual /sample on Navel orange and 231 \& 214 aphids/sample on mandarin trees for the two seasons. While on Valencia orange the number of $M$. persicae per sample increased until reached its peak at the end of March with a total number of 378 and 366 aphids/ sample for the two seasons.

\section{4- Aphis craccivora}

The total numbers of $A$. craccivora collected from tested citrus species are illustrated graphically in figure (4). As shown in figure (4) $A$. craccivora had one peak occurred at mid of April on Navel orange and Mandarin trees with a total number of 363\& 339 and 205\& 198 aphids/sample for the two seasons, respectively. While on Valencia orange the peak was recorded at the end of March with a total number of 407 and 389 individual/ sample for the two seasons. These results agree with those obtained El-Nagar et al. (1984), Ghamry (1986), Ismail et al. (1986), Yakomi, et al. (1996), Attia-Shahinaz (1999) and Amer (2002).

In conclusion, data illustrated in figures (1, 2, 3 and 4) are showed that the number of each aphid population varied among these host plants (Navel orange, Mandarin and Valencia orange). According to Abd El-Kareim (1997) olfactory stimulation produced by citrus leaves may play a role in host recognition by the insect pest. Emission of aciditory stimuli from the host plant is the main factor in insect attractance. 
J. Agric. Sci. Mansoura Univ., 32 (6), June, 2007
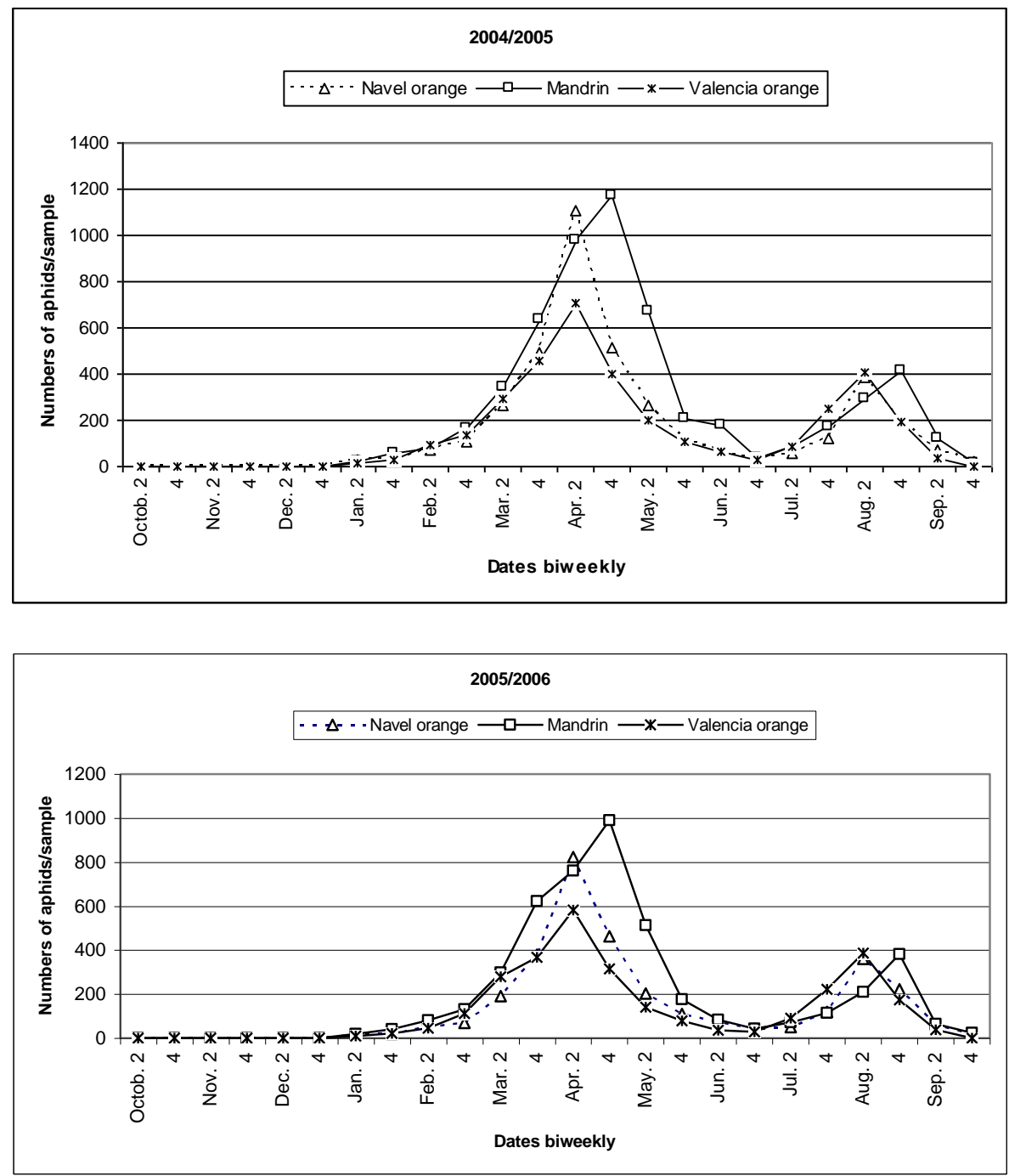

Fig. (1). Seasonal abundance of $A$. gossypii on different citrus host plants (Navel orange, Mandarin and Valencia orange trees) at Mansoura district during 2004/2005 and 2005/2006 seasons. 
El-Gindy, M. A and Ola E. Hegab
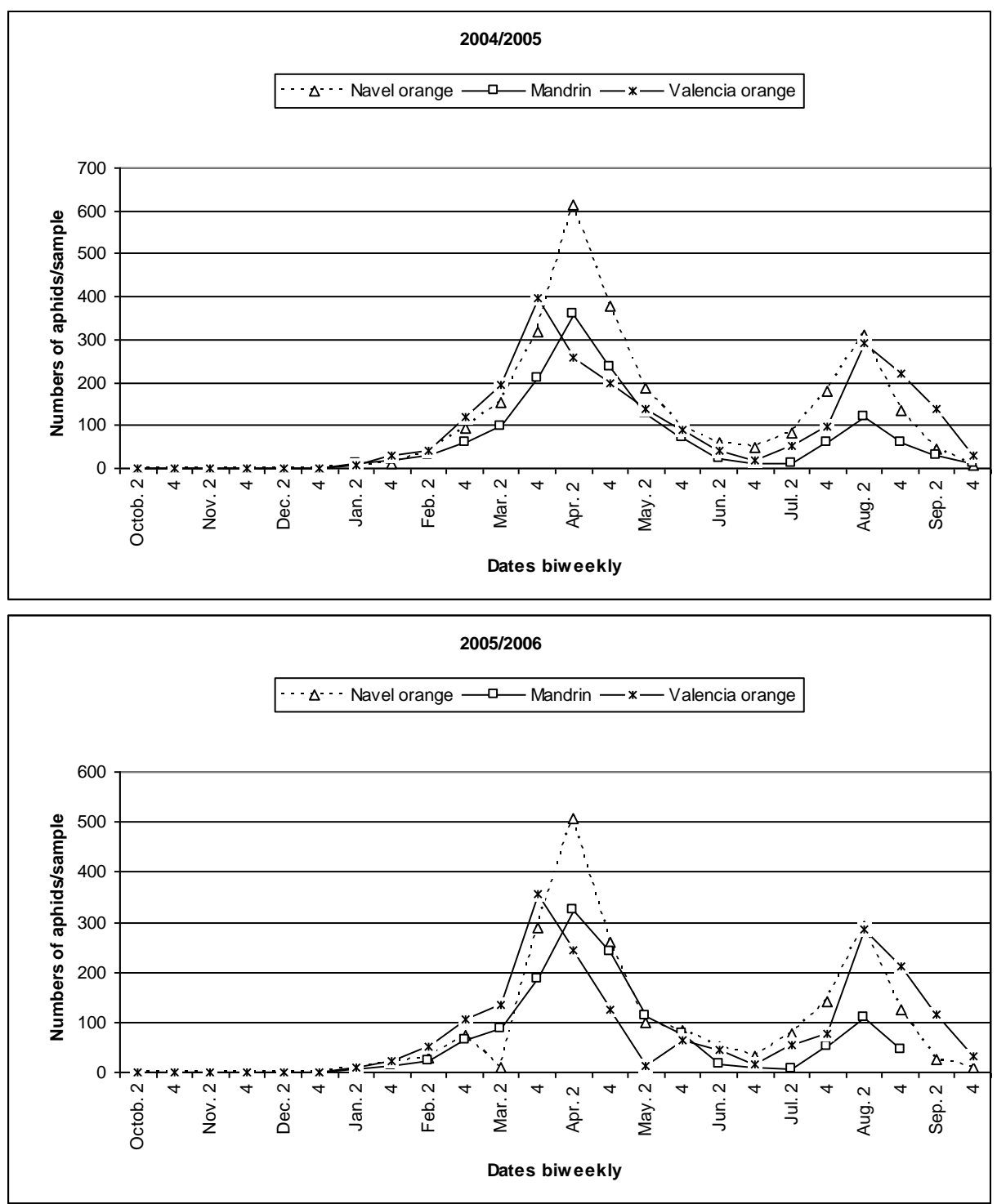

Fig. (2). Seasonal abundance of $A$. citricola on different citrus host-plant (Navel orange, Mandarin and Valencia orange trees) at Mansoura district during 2004/2005 and 2005/2006 seasons. 
J. Agric. Sci. Mansoura Univ., 32 (6), June, 2007
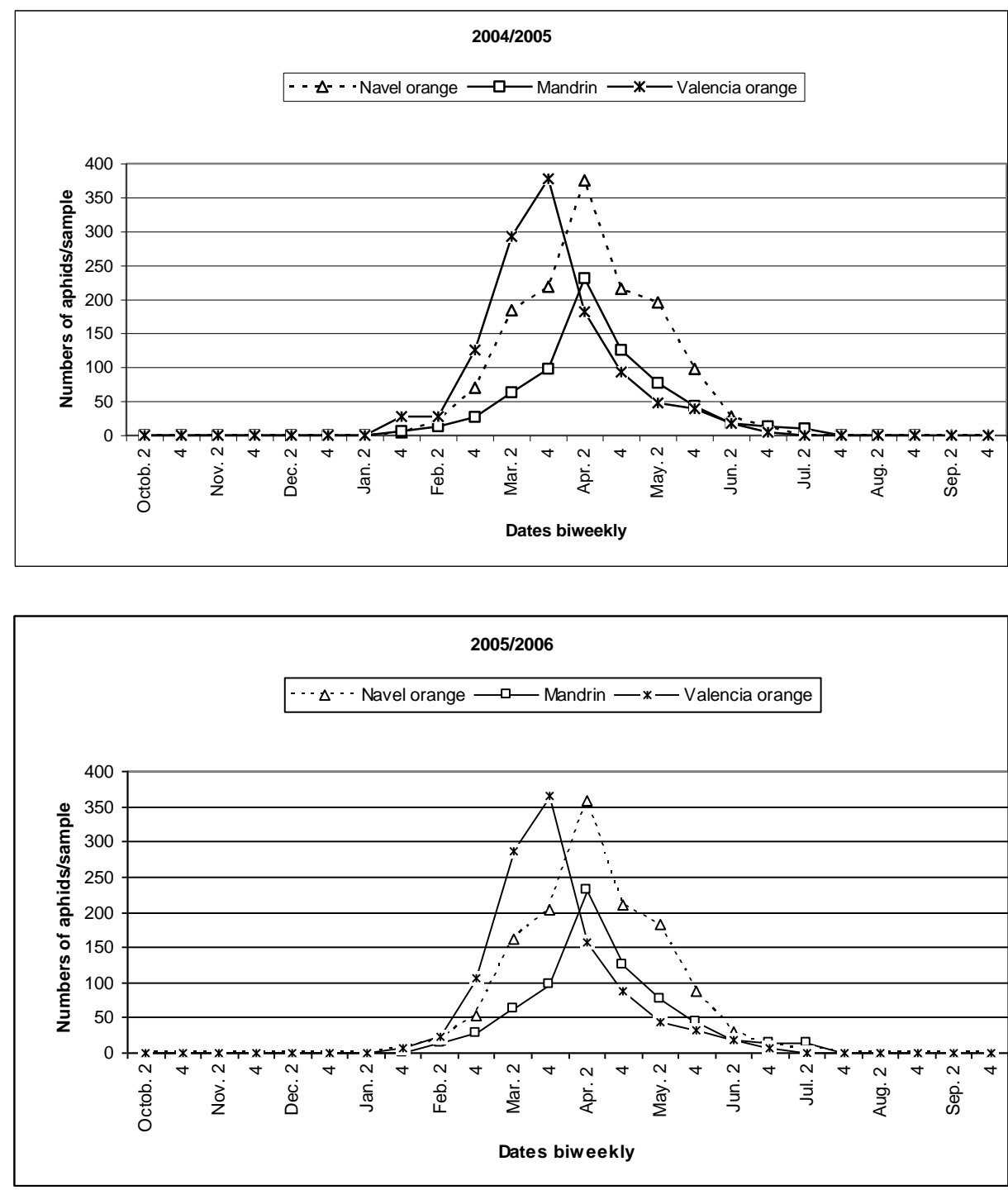

Fig. (3). Seasonal abundance of $M$. persica on different citrus hostplant (Navel orange, Mandarin and Valencia orange trees) at Mansoura district during 2004/2005 and 2005/2006 seasons. 
El-Gindy, M. A and Ola E. Hegab
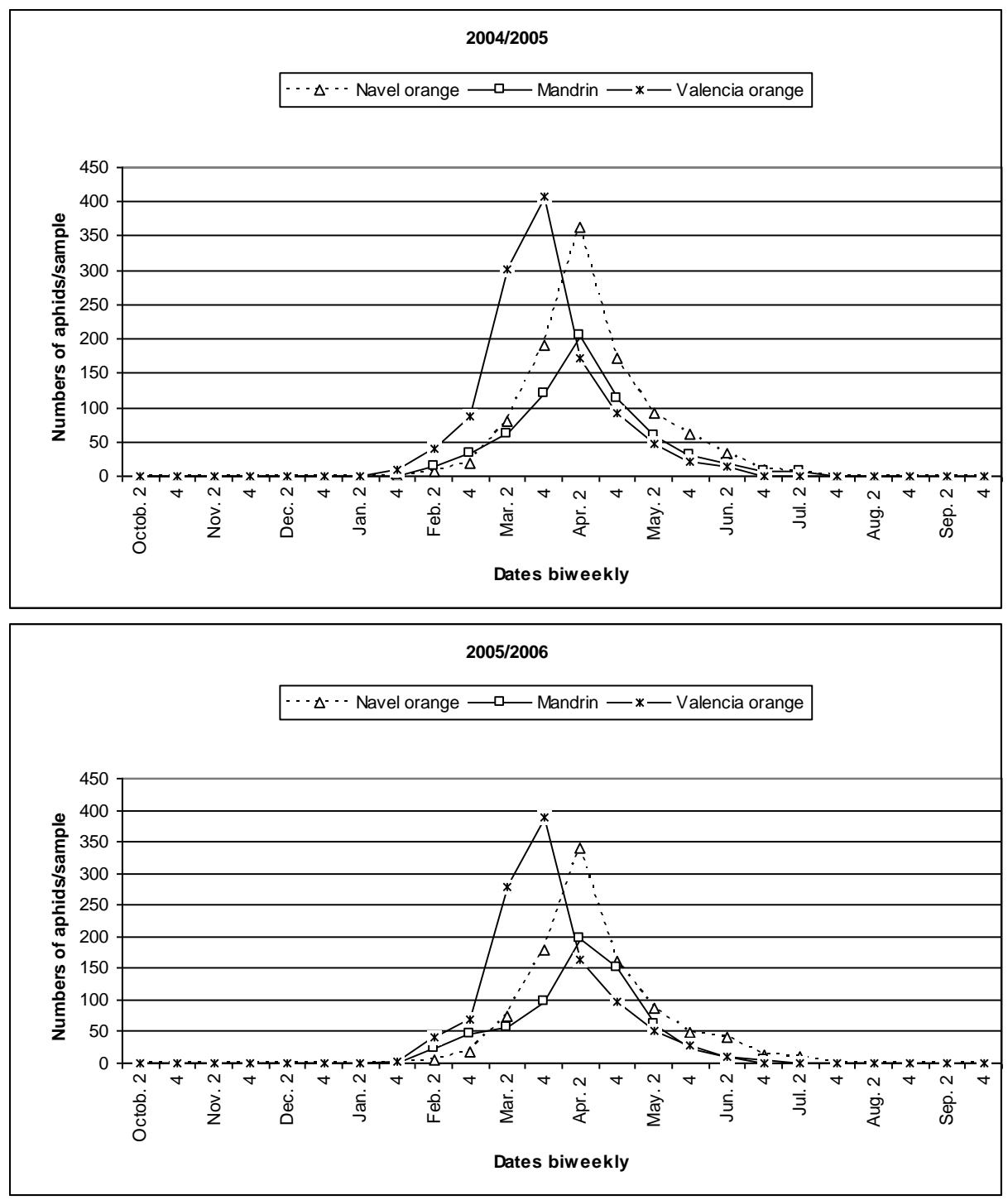

Fig. (4). Seasonal abundance of $\boldsymbol{A}$. craccivor on different citrus hostplant (Navel orange, Mandarin and Valencia orange trees) at Mansoura district during 2004/2005 and 2005/2006 seasons. 
Effect of temperature and relative humidity on the aphid seasonal abundance

Data of simple correlation coefficients between certain climatic factors and the dominant aphid species are tabulated in table (2)

Table (2): Partial regression and simple correlation coefficients between maximum temperature, minimum temperature and relative humidity and the total number of the dominant aphid species infesting citrus trees.

\begin{tabular}{|c|c|c|c|c|c|c|c|c|c|c|c|c|}
\hline \multirow[t]{3}{*}{ Aphid species } & \multicolumn{6}{|c|}{ Simple correlation } & \multicolumn{6}{|c|}{ Partial regression } \\
\hline & \multicolumn{3}{|c|}{$2004 / 2005$} & \multicolumn{3}{|c|}{$2005 / 2006$} & \multicolumn{3}{|c|}{$2004 / 2005$} & \multicolumn{3}{|c|}{$2005 / 2006$} \\
\hline & $\mathbf{r}_{1} 2$ & $r_{1} 3$ & $r_{1} 4$ & $\mathbf{r}_{12} 2$ & $\mathbf{r}_{1} \mathbf{3}$ & $r_{14}$ & $\mathbf{b}_{1}$ & $\mathbf{b}_{2}$ & $\mathbf{b}_{3}$ & $\mathbf{b}_{1}$ & $\mathbf{b}_{2}$ & $b_{3}$ \\
\hline A. gossypii & $\begin{array}{c}{ }^{\star} \\
0.349\end{array}$ & 0.247 & $\begin{array}{c}{ }^{\star} \\
-0.468\end{array}$ & 0.544 & 0.408 & -0.481 & 2.631 & -2.821 & 5.025 & 3.098 & -2.62 & 1.93 \\
\hline A. citricola & -0.088 & 0.018 & -0.381 & -0.245 & -0.314 & 0.187 & -12.007 & 8.226 & -2.093 & 4.56 & 5.10 & 2.63 \\
\hline M. persicae & 0.235 & 0.498 & -0.237 & 0.247 & 0.315 & 0.108 & 8.930 & -1.733 & -1.652 & 4.256 & 5.62 & 5.101 \\
\hline A. craccivora & 0.238 & $\begin{array}{c}{ }^{*} \\
0.499\end{array}$ & 0.278 & $\begin{array}{c}{ }^{\star} \\
0.112\end{array}$ & $\mid-0.253$ & 0.53 & 1.058 & 1.517 & $\mid-1.493$ & 7.68 & 7.71 & 3.115 \\
\hline
\end{tabular}

$\mathbf{r}_{1} 2$ :correlation coefficient between max. temp. and numbers of insects.

$r_{1} 3$ :correlation coefficient between min. temp. and numbers of insects.

$r_{1} 4$ :correlation coefficient between R.H. and numbers of insects.

$b_{1}$ : Partial regression between max. temp. and numbers of insects.

$b_{2}$ : Partial regression between min. temp. and numbers of insects.

$b_{3}$ : Partial regression between R.H. and numbers of insects.

\section{a) Aphis gossypii:}

The correlation coefficient between $A$. gossypii and maximum temperature was positive and significant $\left(\mathrm{r}_{1} 2=0.349^{*}\right)$ in $2004 / 2005$ season but it was positive and insignificant $(\mathrm{n} 2=0.544)$ during $2005 / 2006$ season. The number of $A$. gossypii was positive and insignificant correlated with

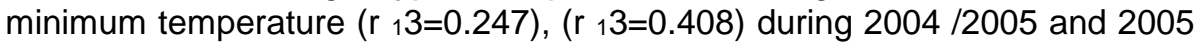
/2006 seasons respectively. The correlation coefficient between the population of $A$. gossypii and relative humidity was negative and significant ( $r$ $\left.14=-0.468^{*}\right)$ during $2004 / 2005$ season but it was insignificant $\left(r_{1} 4=-0.481\right)$ during $2005 / 2006$ season. The partial regression between $A$. gossypii and maximum temperature was positive and insignificant ( $\left.b_{1}=2.631\right),\left(b_{1}=3.098\right)$ during two seasons respectively. While the partial regression between $A$. gossypii numbers and minimum temperature was negative and insignificant $\left(b_{2}=-2.821\right)$ and $\left(b_{2}=-2.62\right)$ in two seasons respectively. The partial regression between $A$. gossypii and relative humidity was positive (b $3=5.025),\left(b_{3}=1.93\right)$ during two seasons respectively.

\section{b) Aphis citricola:}

The correlation coefficient between $A$. citricola and maximum temperature was negative and insignificant $\left(r_{1} 2=-0.088\right)$ and $\left(r_{1} 2=-0.245\right)$ during 2004 $/ 2005$ and $2005 / 2006$ seasons respectively.

The number of $A$. citricola was positive and insignificant correlation with minimum temperature $(r+3=0.018)$ in $2004 / 2005$ season but it was negative and insignificant correlation $(r-3=-0.314)$ in $2005 / 2006$ season. The correlation coefficient between the population of $A$. citricola and relative 


\section{El-Gindy, M. A and Ola E. Hegab}

humidity was negative and insignificant $\left(r_{1} 4=-0.381\right)$ in $2004 / 2005$ season, but it was positively and insignificant correlation $(r+4=0.187)$ in $2005 / 2006$ season.

The partial regression between $A$. citricola and maximum temperature was negative and insignificant ( $\left.b_{1}=-12.007\right)$ in2004/2005 season, and positive insignificant $\left(b_{1}=4.56\right)$ during $2005 / 2006$ season. While partial regression between the number of $A$. citricola and minimum temperature was positive and insignificant $\left(b_{2}=8.226\right)$ and $\left(b_{2}=5.10\right)$ during two seasons respectively. There was negative and insignificant partial regression between the numbers of $A$. citricola and relative humidity $\left(b_{3}=-2.093\right)$ in $2004 / 2005$ season, but it was positive and insignificant $\left(b_{3}=2.63\right)$ in $2005 / 2006$ season.

\section{c) Myzus persicae:}

The correlation coefficient between $M$. persicae and maximum temperature was positive and insignificant $(r+2=0.235),(r+2=0.247)$ during two seasons respectively. The correlation coefficient between $M$. persicae and minimum temperature was negative and insignificant $\left(r_{1} 3=-0.498\right)$ in $2004 / 2005$ season, but it was positive and insignificant $(r+3=0.315)$ in 2005 /2006 season. The correlation coefficient between $M$. persicae and relative humidity was negative and insignificant $\left(r_{1} 4=0.237\right)$ in $2004 / 2005$ season, but it was positive and insignificant $\left(r_{1} 4=0.108\right)$ in $2005 / 2006$ season.

The partial regression between population of $M$. persicae and maximum temperature was positive and insignificant $\left(b_{1}=8.930\right)$ and $\left(b_{1}=4.256\right)$ during both seasons respectively. The partial regression between $M$. persicae and minimum temperature was negative $\left(b_{2}=-1.733\right)$ in $2004 / 2005$ season, but it was positive and insignificant $\left(b_{2}=5.62\right)$ in $2005 / 2006$ season. The partial regression between $M$. persicae and relative humidity was negative (b $3=1.652)$ in $2004 / 2005$ season .but it was positive and insignificant $\left(b_{3}=5.101\right)$ in $2005 / 2006$ season.

\section{d) Aphis craccivora:}

The correlation coefficient between $A$. craccivora and maximum temperature was negative and insignificant $\left(r_{1} 2=-0.238\right)$ in $2004 / 2005$ season, but it was significant $\left(r_{12}=-0.112^{*}\right)$ in $2005 / 2006$ season. The population of $A$. craccivora was negative and significant with minimum temperature $\left(r_{1} 3=-0.499^{*}\right)$ in $2004 / 2005$ season, but it was negative and insignificant $\left(r_{1} 3=-0.2583\right)$ in $2005 / 2006$ season. The correlation coefficient between $A$. craccivora and relative humidity was negative $\left(r_{1} 4=-0.278\right)$ in $2004 / 2005$ season, but it was positive and insignificant $\left(r_{1} 4=0.53\right)$ in 2005 /2006 season.

The partial regression between population of $A$. craccivora and maximum temperature was positive and insignificant $\left(b_{1=1.058}\right),\left(b_{1=}=7.68\right)$ during two seasons respectively. The partial regression between $A$. craccivora and minimum temperature was positive and insignificant $\left(b_{2}=1.517\right)$ and $\left(b_{2}=7.71\right)$ for both seasons respectively. The partial regression between $A$. craccivora and relative humidity was negative $\left(b_{3}=-1.493\right)$ in $2004 / 2005$ season, but it was positive and insignificant $\left(b_{3}=3.115\right)$ in $2005 / 2006$ season. 
These results ensure that the tested weather factors play a great role in regulating the population density and seasonal abundance of such aphid species. (2001).

The same results were reported by El- Gindy (1997) and Hegab- Ola

\section{REFERENCES}

Abd El-kareim, A.I. (1988): The biology of red pear and oleander scale and possible control methods by Juvenoids and precocenes. Ph.D Thesis, Plant Prot. Dept.Budapest, Hungary.

Abd El-kareim, A.I. (1997): sex pheromone and plant odor as behavioral chemical for the citrus leafminer, thyllocnistis citrella stainl Clepidoptera: Gracillariidae). $7^{\text {th }}$-Nat. Conf. of pest\& Dis. of vegetables\& fruits in Egypt, 1997.

Amer, S.A. (2002): Studies on certain plant pathogenic insect vectors. (M.Sc.Thesis, Fac., Agric., Zagazig Univ.) Egypt.

Argyrious, L.C. (1970): Aphids injurious to citrus in Greece and their natural enemies. Annales de,Institute phytopathologiue Benaki (N.S.),8(2): 114-117.

Attia, A.A. (1983): Studies on the aphid fauna of fruit trees in Egypt. Thesis of Ph. D., Ain Shams Univ., Egypt.

Attia, A.A.; El-Kady, E.A. (1986): The seasonal abundance of Aphis citricola V.D. Goot on certain fruit trees . Bull. Soc. Ent. Egypt, 66:279-283.

Attia - Shahinaz, (1999): Studies on the aphid fauna of Sinai Governorate. (Ph. D., thesis , Fac., Agric., Cairo univ.) Egypt.

Bertolini, E., Cambra, M., Martinez, M.c., Olmos. A.,Marroquen, C., Gorris, M.T., Carbonell, E.A. and Hermoso de Mendoza, A.(2004): Estimation of the number of aphids carrying citrus tristeza virus that vist adult eitrus trees. Virus Research, (Vol.100) (No.1) 101-108.

Chen, D.; Wong,R. (1998): The dominant citrus aphid species causes of outbreaks and control strategy. South China fruits 27(4) 16-17.

El- Gindy, M.A (1997) : Studies on certain homopterous insect infesting some vegetable in Dakahlia Governorate.

El-Naggar, S.; Ismail, I.,I. and Attia, A.A. (1984): Seasonal abundance of Aphis gossypii (Glover) on certain fruit trees. Bull. Soc. Ent., Egypt, 65: 27-32

Ghamry, M. S. (1986): The role of plant natural products on aphid infesting citrus trees of Sharkia Governorate(M.Sc. Thesis, Fac., Agric., Zagazig Uni.) Egypt.

Habib, A. and El-kady,E. (1961): The Aphididae. (Bull. Soc. Ent. Egypt, 45: 117-119).

Hegab- Ola , I.M.S. ( 2001 ) :Studies on certain insect vectors of plant pathogenic agents (Ph.D. of Science Fac. Agric. Zagazig Univ.)

Ismail, II., El-Nagar, S. and Attia, A. A. (1986): The aphid fauna of fruit trees in Egypt. African J. of Agricultural Science 13(1+2): 1-7. 


\section{El-Gindy, M. A and Ola E. Hegab}

Savb, J (1973): biometrial modszerek a Kutatashan ( Mezogazedasagi Kiado, Budapest).

Yakomi, R.K. and Tand, Y.A. (1996): A survey of parasitoids of brown citrus aphid (Homoptera : Aphididae) in Puerto Rico. Biological control. 6(2): 222-225

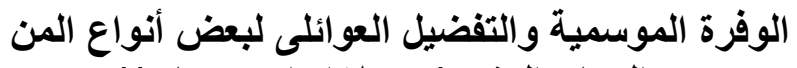

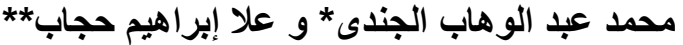

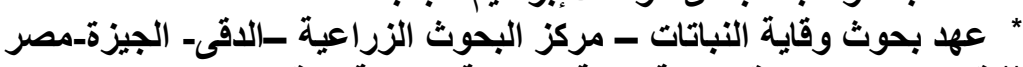

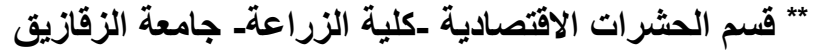

أجريت هذه الدراسة فى منطقة المنصورة- محافظة الدقهلية فى مساحة منزرعة بأثنجار

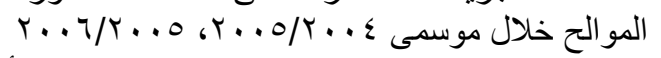

تم در اسة الوفرة الموسمية و التفضيل العو ائلى لبعض أبوان أنواع المن:

A. gossypii

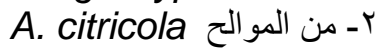

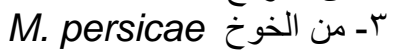

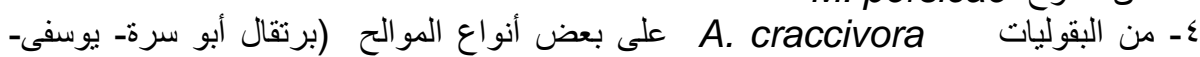

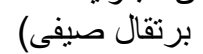

وقد تم استخدام طرق مختلفة لأخذ العينـات ( العينة النباتية، المصائد الصفر اء اللاصقة،

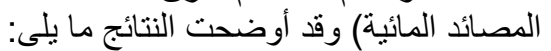

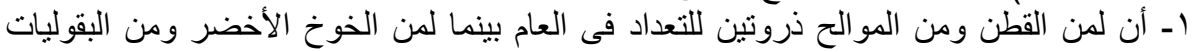

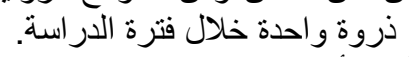

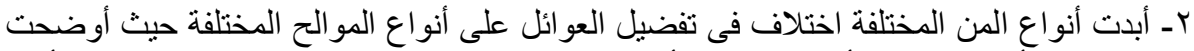

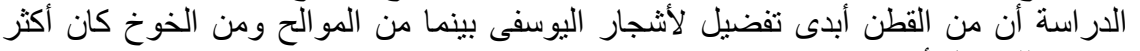

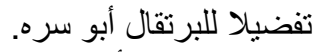

بـ أظهرت الدراسة أن درجات الحرارة والرة الرطوبة النسبية تؤثر على الوفرة الموسمية تأثير ا معنويا

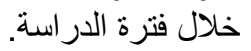

